\title{
Development and Contribution of Open Source Software Communities for the Library Progress in Indonesia
}

\author{
Resty Jayanti Fakhlina ${ }^{1}$, Dwi Fajar Saputra ${ }^{2}$ \\ ${ }^{1}$ Dosen Prodi Ilmu Perpustakaan UIN Imam Bonjol PadangHead of \\ ${ }^{2}$ Kepala Perpustakaan Fakultas Kedokteran UPN Veteran Jakarta
}

\section{Abstract}

Background of the study: Open source software is an open-based software and can be accessed for free. This open source software is growing rapidly at domestic and overseas. Many criteria are used by users. In this case, the library Also, choosing the open source software they need. There are several organization that a accommodate Review these users of open source software in Indonesia. Some of the open source software is the Slims organizes community and Surabaya's Linux Community.

Purpose: The purpose of this study was to determine the development and contribution of the community to libraries in Indonesia.

Method: The method used is a qualitative method with a descriptive approach.

Findings: The results of this study are the Open Source Community the which plays an important role in the progress of libraries in Indonesia, this can be seen from the number of school libraries that have implemented an IT in providing services to users by using open source software.

Conclusion: The conclusion is the development and contribution of the Open Source Community in Indonesia is needed for the progress of the library in the future.

Keywords: Open Source Software, Open Source Community, Library, Slims, and Linux.
Paper Type:

Research Paper

Submitted 29 April 2019 Accepted 22 December 2019

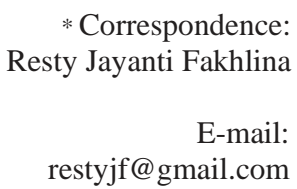

To cite this document:

Fakhlina, R.J., \& Saputra, D.F. (2019). Development and Contribution of Open Source Software

Communities for the Library Progress in Indonesia. Record and Library Journal, 5(2), 150 - 159. 


\section{Introduction}

Libraries as management of information services cannot turn away from the advancement of information and communication technology. Various software (software) is provided to support the needs of libraries in the running of the organization and provide services to users. Software mentioned there are paid, which is leased, the software is free but has a period of usage, and based on the public domain, as well as based open.

For paid software, we have to pay in advance if we want to use the library. This happens because the purpose of a commercial nature. Examples of paid software include Microsoft Windows, Adobe Photoshop, Macromedia Flash full version, adobe acrobat, Zope, and others. Software that is leased known as rental ware. Technical usage is when they are discharged rental ware period / rental limits, then the software will lock itself. And if you want to use the software again, we have to extend the contract. Rental ware based software examples include Macromedia Dream Weaver, Norton Utilities, Indobilling, and others. While shareware is software that can be used for free, but for a certain period.

The next type is public domain software. This software is not protected by copyright. Full version and the source code are freely available to be modified, and redistributed by any licensing. Sample-based software in the public domain, among others STP MP3 Player, GNU / Linux, Apache, MySQL.NU/Linux, and others. The latter is a type of software based on open source. This software is free and the source code is open to the public. Open source can be modified again according to our needs. The code contained in this kind of software we can take and develop. Example based on open source software among others Eprints, DSpace, Omeka, Koha, Slims, SETIADI, OJS and others.

Based on open source software is a software most widely used by the library. This occurs because the library as a non-profit institution, often have a low budget operation.

Various open source user organizations have sprung up in Indonesia. Among them are the Community Slims Banten, Jakarta, Lampung and Linux Arek Suroboyo group. In this article we review the development of these communities and contributing to the advancement of libraries in Indonesia.

\section{Method}

Qualitative method to descriptive approach. Data were collected by conducting interviews, and literature. Informants for this study is the Head and members of the Community Slims Banten, Jakarta, Lampung and Linux Arek Suroboyo group. Interviews were conducted in April 2019 from 8-12 to 4 informants. The data were analyzed descriptively. Data collection is done through the interview process, and then the data reduced, further presentation of data, then the last performed data interpretation.

\section{Result and Discussion \\ Software Based Open Source}

The Software is based on open source software that has the source code under the auspices of the license. Open source was first developed in the 1970s by Richard Stallman, from MIT who coined the term "free software". Richard and others dissatisfied with the restrictions of proprietary software vendors and currently there is a tendency increasing number of vendors of proprietary software (closed source) (Appelbe, 2003). 


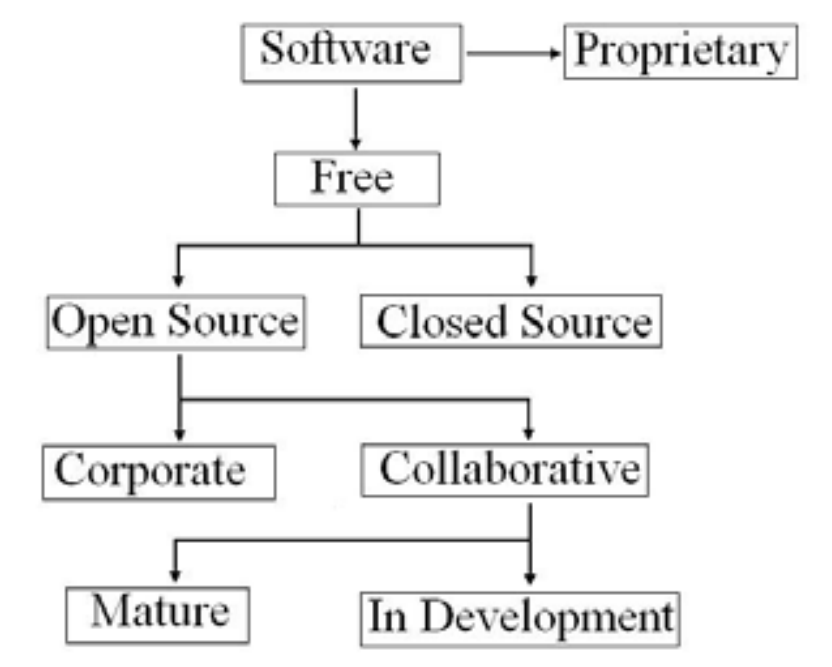

Figure 1. Taxonomy Software (Source: Wei, 2011)

For several decades, based on open source software have claimed a large market share of the computer industry, and a large number of the software is available on the Internet. Metcalfe \& Rahtz (2006) stated that the reason users prefer based on open source software include: 1. The minimum procurement costs; 2 . The possibility of the total cost of ownership (although this is the subject of debate); and 3. increased power to customize the software to the specific needs of end users.

Open-source phenomenon raises many interesting questions. Advocates regard it as an economic paradigm shift where personal belongings, which is built on scarcity of resources, to be replaced by economic public goods, where scarcity is no longer a problem (Hars, 2002). Presence and success based on open source software movement, often characterized as a fundamentally new way to develop software, and so pose a serious challenge for a software engineering approach that is more traditional (Mockus et al. In Ducheneaut, 2005).

The basic philosophy is based on open source software is very simple. When programmers are allowed to work freely in the source code of a program, this will definitely be increased because of the collaboration helps to correct the error and allow adaptation to the different needs and hardware platforms. It actually has happened and based on open source software is well-known today for the level of reliability and high portability. (Bonaccorsi, 2003).

Schlumpf (in Setiawan, 2017) explains that the open source movement is a phenomenon that affects the software industry in a fundamental way and represents a paradigm shift in terms of how software is developed, marketed and used.

The Open Source Definition reveals that there are ten criteria which states that the software can be called based on open source (in Wei, 2011):

To cite this document:

Fakhlina, R.J., \& Saputra, D.F. (2019). Development and Contribution of Open Source Software

Communities for the Library Progress in Indonesia. Record and Library Journal, 5(2), 150 - 159. 
1. Free redistribution: Software will be available without making payments.

2. Source code : Software will be distributed with its source or published with free access.

3. Derived works : License must allow modifications and derived works, and must allow them to be distributed under the same conditions with the license of the original software.

4. The integrity of the author's source code : Distribution of "patch files / file patch" used to re-create derivative works are permitted.

5. No discrimination against persons or groups : License must not discriminate against any person or group of people.

6. No discrimination against fields of endeavor : For example, the software is not limited to use in the business world as well as for genetic research.

7. Distribution of license : The rights attached to the software must be applicable to all of its peoples' software redistributed without the need for execution of an additional license by those parties.

8. $\quad$ The license must not be specific to a product $:$ License rights should not depend on software distributed with other specific software.

9. The license must not restrict other software : License must not restrict other software that is distributed along with the licensed software.

10. A License must be technology-neutral : No provision of the license may be based on technology or style of interface whatsoever.

Figure 2. The Open Source Definition (Source: Wei, 2011)

\section{Open Source Community in Indonesia}

Software based on open source has changed the world of software development. Some of the unique activities in the open source community to emerge as a clear modular approach to the design of software; meritocracy, peer-reviewed style in project management; and a substantial reliance on volunteers (Aberdour, 2007). The role of community that develops voluntary innovation and disseminate to its members lately been observed in a variety of fields, one of them as open source software (Lakhani and von Hippel, 2003; Lee and Cole, 2003).

The term community is the meaning of the English "community" comes from the Latin "Communities". The community is composed of two syllables, namely com which means together and munus which means gifts. Communities can be defined as a group of people who share a common interest in order to achieve a variety of things. In this case, the community in a variety of fields related to software based on open source. (Maryanto, 2017).

Moreno Muffatto explain community consists of five players and three categories or roles. Five categories are regular users (users), users who are also developing (prosumers: producers and consumers), the main developer (leader teams), enterprises (companies), and non-enterprise institutions (institutions) such as universities and governments. The fifth type of community it can have three roles in the software development process, namely as a customer (customer), development actors (actor), and decision makers in the development (decision maker). That is, users also play a role as development actors by giving feedback or suggestions to the primary developer, and also play a role in testing the quality of open-source products. Similarly the company,

According to Saputra (2015), software development libraries involve three parties, namely

To cite this document:

Fakhlina, R.J., \& Saputra, D.F. (2019). Development and Contribution of Open Source Software

Communities for the Library Progress in Indonesia. Record and Library Journal, 5(2), 150 - 159. 
the formal institutions, third-party agencies and non-formal (community). In Indonesia, since 2017 there are some communities that emerged as the open source community activists library field. It is the same with the birth of Slims software. Slims (Senayan Library Management System) is an open source software based on the original made in the nation. Created and developed by Arie Nugraha and Hendro Wicaksono in 2007. Today Slims been used by many libraries in Indonesia and some overseas territories. This slims software can be downloaded via the Web Slims with address https://slims.web.id/web/,

Slims spread out inside and outside the country through its communities. Slims user communities usually represent the area of each member. As Community Slims Jakarta, Community Slims Banten, Lampung Community Slims, and so forth. Here are some communities slims the author interviewed for this article, data completeness, IE Community Community Slims Slims Banten and Lampung.

Banten Slims Community first established on October 1, 2014. This was stated by Chairman of the Community Slims Banten, Mr. Iskandar Bajang, that

"Community Banten Slims first formed on 1 November 2014 by Fajar Dwi Saputra as a fiduciary of the Community Slims Jakarta. Community formation Banten Slims held at the campus of the University of Muhammadiyah Tangerang FISIP with the workshop participants attended the invitation of the Community Slims Jakarta. Community Events Slims Banten formation was opened by Mr. Dean of the Faculty of Social UMT. "(Interview with Iskandar Bajang, as Chairman of the Community Slims Bantam).

Based on the results of these interviews, information was obtained that the Community Slims Banten inaugurated by the Dean of the Faculty of Social and Political Sciences, University of Muhammadiyah Tangerang and shaped by Fajar Dwi Saputra Slims as the envoy of the Community of Jakarta. Further, when it will be formed regeneration stewardship of caretaker first. This is explained by Iskandar Bajang.

"Over thanks to Rahmat Allah and the efforts of the friends of the Community Slims Jakarta such as Danang Dwi Agung Widodo Kangko and Waris, who gave the mandate to co Fajar Dwi Saputra then formed Community Slims Banten. Then, after the establishment of the Community of Slims Banten some community service has been carried out at various campus locations in Banten, various other events SEGI (Session Sharing) so the designation of the crew Community Slims Banten, event SEGI was organized in cooperation with the Community Slims Bantam with several universities and Banten Provincial Archives Agency business. Community stewardship Banten Slims held directly by the founder of the Community Slims Banten as the embodiment of responsibility and fiduciary and assisted by colleagues in Banten as Iskandar, Nurcholis, Ricky Nopradita and others. Until now, the management of the Community Slims Banten Vol 2 will be formed. "(Interview with Iskandar Bajang, as Chairman of the Community Slims Bantam).

While the Slims Community Lampung formed on March 18, 2013:

"Originated from the curiosity of school librarian / colleges and students to the automation library, then in March SLIMS community first established in SMAN 2 Bandar Lampung. From there the embryo of Community SLIMS Lampung formed, followed by approximately 4 participants from the background of the librarian. " (Interview with the Executive Board Slims Community Lampung).

Lampung Slims community is motivated by some librarians and students about library automation. And their condition at the time the meeting took place, have not been able to do the installation of the Software Slims. In addition, at the meeting, the board also directly formed Slims Community Lampung.

"In March 2013, at SMAN 2 Bandar Lampung Lampung formed SLIMS Community officials. Which consists of the Coordinator: Arif Isnaini, S.Pd I (SMAN 9 Bandar Lampung), Secretary / Treasurer: Yunidar, A.Md (SMAN 2 Bandar Lampung), PR: Haryo, A.Md (SMPN 1 Bandar Lampung), Cooperation and Products: Darma, A.Md (SMA.N 10 Bandar Lampung). In this

To cite this document:

Fakhlina, R.J., \& Saputra, D.F. (2019). Development and Contribution of Open Source Software

Communities for the Library Progress in Indonesia. Record and Library Journal, 5(2), 150 - 159. 
activity the participants Lampung Community SLIMS still learning how to install the program SLIMS, because there are many participants who do not understand how to install SLIMS program. " (Interview with the Executive Board Slims Community Lampung).

Community members Slims recruitment process is generally done after the participants through training, workshops, Sinau, and Session Sharing Slims. Event recruitment / admission Lampung Slims members generally set in the AD / ART Slims Community Lampung is written in the household budget MEMBERSHIP Chapter I, Article 2 of the mentioned Member Reception: 1) Prospective members fill out a membership form issued by Slims community Lampung; 2) Prospective members meet the administrative requirements; 3) When meeting the requirements of paragraph (1) and (2) the prospective member is given a membership card.

Note: Administrative requirements are; 1) Photo 2X3 and 3X4 1 sheet 3 sheet. 2) The registration fee of Rp.15,000 (fifteen thousand rupiah) 3) Pay dues each meeting Rp.5.000, - (five thousand rupiah).

Generally Slims each community has activities such as Sinau, upgrading of management, cooperation help implements slims, frequently asked questions in social media, TOT, workshops, and other activities. Especially for Community Slims Lampung, more structured activities, as described by managers as follows:

"This community has set an outline of some routines carried out every week. The work program and agenda of community activities is designed to run in a period of 2 (two) years and will be adjusted again in the work program and agenda of the 2 (two) following year. Routine activities are Sinau Communities Together (Learning Together) and Coding Together; Sharing / discussion Slims Additional Activities such as Open Workshop by bringing in professional speakers; Social activities; and cooperation with students of Library Science. "(Interview with the Executive Board Slims Community Lampung).

In addition to emerging community for open source-based software Slims, there is also a community formed in Linux software. One is a group of Linux Arek Suroboyo. Linux group Arek Suroboyo or so-called KLAS (website https://klas.or.id/) Up from 1994, when the initial linux entering Indonesia. In initiated by senior KLAS some of which Mr. Agus Rubiyanto, Mr. WIMA Sangga, Mr. Noor Al Azam. The background with the hope to learn together, share knowledge to, the public about Linux and open source applications. The process of withdrawal of members is relatively easy, just join the Facebook of KLAS. The spirit that run relatively active. Having a monthly event like Cangkru'an KLAS.

\section{Development and contribution to the Open Source Community Library in Indonesia}

Libraries have started using software based on open source for various application libraries, one of the most prominent purpose is to build a digital library. In digital preservation, this software plays an important role in the adaptation of technology for the library based on open standards, which is an important criteria in support of digital preservation. An open standard with no rights of ownership allows the library to become transient towards migration (Madalli, 2012). To create a digital library, a tool for software based on open source is increasingly considered as an alternative to digital library system because of dissatisfaction with commercial software, mainly because of the lack of functionality, cost, inadequate support, and others (Breeding, 2012).

Software based on open source library of the most famous in Indonesia at this time includes SLIMS, Koha, NewGenLib, and so forth. But there is also some software based on open source software outside the library, but are directly related to the performance of the library, such as LINUX.

\section{Community Slims Jakarta}

Communication with users Slims have a harmonious relationship of community members, mostly work of librarians and teachers that know the needs of users Slims. Then the user slims basic

To cite this document:

Fakhlina, R.J., \& Saputra, D.F. (2019). Development and Contribution of Open Source Software

Communities for the Library Progress in Indonesia. Record and Library Journal, 5(2), 150 - 159. 
use of software Slims such as easy in implementation, many hints on search sites or YouTube, do not rely on developers if they are busy, librarians easily expand it back (according to the needs of the library), free of charge, many free plugins contrast with paid software. Going forward Slims Jakarta plans to expand by opening branches in new areas, because there are still a lot of development needs in each region, because according to the Jakarta Slims library board is currently being passionate. Other contributors want to do coaching for free.

\section{Community Slims Banten}

For Slims Community Banten have training programs, workshops, study together \& Training of Trainers. Relationships with users Slims very good and mutual benefit between the library and the community. And almost $90 \%$ of community members and administrators Slims is the library, so that they can understand each other. The reason of the Slims Slims why they chose that the app is free, makes easily provide services to visitors and help librarians create reports in the form of library automation. Expectations of future Banten Slims community will be a community or institution that would be a good example in the development of the library world by continuing to organize activities that attract and spread of science and technology library of the latest reply to the librarian and literacy activities. Namely, that the greatest contribution that libraries managed by every member of increased quality and service, especially in the field of automation and collaboration between libraries.

\section{Community Slims Lampung}

The relationship between the library community are closely interwoven, which in its activities, not only slims community activities or discussion of any digital library, but how can promote the library with the times. It is strongly supported by the community members $95 \%$ Slims Lampung is the manager / librarian. According to them, for the moment a lot of attempts software development library developed by various parties, both the companies and individuals, but with fees and rates are expensive so the library school is not able to afford it. With the open-source software, libraries specifically for school level who do not have sufficient funds to get the software for free so that helps in the process of its financing. For in Lampung itself has many schools and universities using open source program slims it, because the process of getting and easily learned by the manager / library. The Lampung future Slims community has the spirit to keep up with technology and knowledge is increasing, but not balanced with concern for libraries, particularly in schools that do not have a budget and sufficient funds for the development of digital libraries, Lampung Slims community effort and sought to libraries, especially in Lampung province can take advantage and get the open source application is free and is expected Lampung Slims community can become a pioneer in the development of Slims especially in Lampung Province. Technically contributions already made. The activities of Community Slims Lampung has been done until now has been a lot done as conducting seminars / training / bimtek at least 1 year the Province of Lampung, in cooperation with the Department of Libraries and Archives of Lampung Province, in cooperation with organizations, libraries (ATPUSI, IPI, MKPPS, etc.), enter material slims every training activity Library Head undertaken by other organizations.

\section{Linux group Arek Suroboyo (KLAS)}

KLAS more direct themselves involved in ICT activities is generally based on open source. At present there is cooperation with the other IT community, the campus, the provider of internet service providers, and providers vps providers. For this community membership yet no reply works as a librarian or manager of information services institutions, but participants in the activities of the profession KLAS are never a Librarian. According to them, for software that can be used in the scope of the library include LibreOffice, Inkscape, Gimp and gcompris. Meanwhile, with regard to the importance of the use of FOSS is based on personal experience that using FOSS can save the

To cite this document:

Fakhlina, R.J., \& Saputra, D.F. (2019). Development and Contribution of Open Source Software

Communities for the Library Progress in Indonesia. Record and Library Journal, 5(2), 150 - 159. 
cost of purchasing lincense, especially if the license annually and also trains themselves to be independent troubleshooting. He expects that the community is able to continue to be consistent KLAS to disseminate knowledge related to FOSS. The contribution made by KLAS is trying every month training related to ICT-based FOSS. Some of the training we already carry such as Linux Fundamentals, Linux Server Administration, Training LibreOffice, Inkscape Training, Training and Coaching Android Apps IOT.

\section{Conclusion}

Based on open source software depicts a very exciting opportunity for libraries to develop themselves according to their needs. This occurs because the software is open, allowing the library to participate in developing systems and library services directly corresponds to the field of library science. The source code is licensed to users of software freely modify, distribute, and run the program, according to need without having to pay royalties. In its movement, the Open Source community in Indonesia has contributed a great deal in bridging the ICT progress with the development of libraries in Indonesia.

\section{Acknowledgement}

Thanks to the Chairman and Members of the Open Source Software community in Indonesia, which has become informants in this study.

\section{References}

Ancrenaz, M., Dabek, L., \& O'Neil, S. (2007). The costs of exclusion: Recognizing a role for local communities in biodiversity conservation. PLoS Biology, 5(11), 2443-2448. doi:10.1371/journal.pbio.0050289

Appelbe B. (2003). The future of Open Source Software. J Res Pract Inf Tech (35), 227-236.

Aberdour, M. (2007). Achieving quality in open source software. IEEE Software, 24(1), 58-64.

Bagozzi, RP, and Dholakia, UM (2006). Open Source Software User Communities: A Study of Participation in the Linux User Groups. Management Science, 52(7), 1099-1115. doi: 10.1287 / mnsc. 1060.0545

Breeding, Marshall. (2002). An update on the Open Source ILS. Information Today, 19(9), 42-43. (Available at http://www.onlineinc.com/it/oct 02 / breeding.htm).

Bonaccorsi, A., and Rossi, C. (2003). Why Open Source software can succeed. Research Policy, 32(7), 1243-1258. doi: 10.1016 / s0048-7333 (03) 00051-9

Crowston, K., Li, Q., Wei, K., Eseryel, UY, and Howison, J. (2007). Self-organization of teams for free / libre open source software development. Information and Software Technology, 49(6), 564-575. doi: 10.1016 / j.infsof.2007.02.004

Dahlander, L., and Magnusson, MG (2005). Relationships between software companies and open source communities: Observations from Nordic firms. Research Policy, 34(4), 481-493. doi: 10.1016 / j.respol.2005.02.003

Ducheneaut, N. (2005). Socialization in an Open Source Software Community: A Socio-Technical Analysis. Computer-supported cooperative work (CSCW), 14(4), 323-368. doi: 10.1007 / s10606-005-9000-1

Gulati, R., Puranam, P., and Tushman, M. (2012). Meta-organization design: Rethinking design in interorganizational and community Contexts. Strategic Management Journal, 33(6), 571586. doi: 10.1002 / smj. 1975

Hars, Alexander and Ou, Shaosong. (2002). Working for Free? Motivations for Participating in Open-Source Projects. International Journal of Electronic Commerce, 6(3), 25-39. doi: 10.1080 / 10864415.2002 .11044241

Kaufman, C., Perlman, R., \& Speciner, M. (1995). Network Security: Private communication in a public world. Englewood Cliffs, NJ: Prentice Hall.

To cite this document:

Fakhlina, R.J., \& Saputra, D.F. (2019). Development and Contribution of Open Source Software

Communities for the Library Progress in Indonesia. Record and Library Journal, 5(2), 150 - 159. 
Lakhani, KR and von Hippel, E. (2003). How Open Source Software works: "free" user-to-user assistance. Research Policy, 32, 923-943.

Lakhani, KR, Wolf, B., Bates, J., and DiBona, C. (2002). The Boston Consulting Group Hacker Survey. (Available at:http://www.osdn.com/bcg/.)

Lee, GK, and Cole, RE (2003). From a firm-based to a community-based models of knowledge creation: the case of the Linux kernel development. Organization Science, 14(6), 633-649.

Lee Endres, M., Endres, SP, Chowdhury, SK, and Nature, I. (2007). Tacit knowledge sharing, selfefficacy theory, and application to the Open Source community. Journal of Knowledge Management, 11(3), 92-103. doi: 10.1108 / 13673270710752135.

Lerner, J. (2005). The Scope of Open Source Licensing. Journal of Law, Economics, and Organization, 21(1), 20-56. doi: 10.1093 / jleo / ewi002

Saputra, DF (2015). Institutional Repository Based Omeka (Case Study in Medical Knowledge Center - FK UPNVJ). Journal of Library Science, Information and Archives Khizanah AlHikmah, 3(1), 11-19. Retrived from http://journal.uin-alauddin.ac.id/index.php/khizanah-alhikmah/article/view/585

Martin, K., and Hoffman, B. (2007). An Open Source Approach to Developing Software in a Small Organization. IEEE Software, 24(1), 46-53. doi: 10.1109 / ms.2007.5

Maryanto, Rusmanto. (2017). OPN Community Source. (Available at:https://www.academia.edu/5833692/Komunitas_Open_Source)

Metcalfe, R., and Rahtz, S. (2006). Open source software. (Available at: http://www.jisc.ac.uk/media/documents/publications/osswatchbp.pdf)

O'Mahony, S., and Ferraro, F. (2007). The Emergence of Governance in an Open Source Community. Academy of Management Journal, 50(5), 1079-1106. doi: 10.5465 / amj.2007.27169153

Oh, W., and Jeon, S. (2007). Herding and Network Stability Membership in the Open Source Community: The Ising Perspective. Management Science, 53(7), 1086-1101. doi: 10.1287 / mnsc.1060.0623.

Setiawan. (2017). Comparative Analysis of Open Source (Open Source) Integrated Library Management System between Koha and NEWGENLIB. Pustakaloka, 9(2), 312322. (Available

at:https://www.researchgate.net/publication/323755318_Analisis_Komparatif_Sumber_Teb uka_Open_Source_Sistem_Manajemen_Perpustakaan_Terpadu_Antara_Koha_dan_Newge nlib.

Shahrivar, S., Elahi, S., Hassanzadeh, A., \& Montazer, G. (2018). A business model for commercial open source software: A systematic literature review. Information and Software Technology. doi: 10.1016 / j.infsof.2018.06.018

Stewart, D. (2005). Social Status in an Open-Source Community. American Sociological Review, 70 (5), 823-842. doi: 10.1177 / 000312240507000505

Valverde, S., Theraulaz, G., Gautrais, J., Fourcassie, V., \& Sole, RV (2006). Self-Organization Patterns in Wasp and Open Source Communities. IEEE Intelligent Systems, 21(2), 36-40. doi: 10.1109 / mis.2006.34

Valverde, S. and Solé, RV (2007). Self-organization versus hierarchy in the open-source social networks. Physical Review E, 76(4). doi: 10.1103 / physreve.76.046118

Van Wendel de Joode, R., and de Bruijne, M. (2006). The Organization of Open Source Communities: Towards a Framework to Analyze the Relationship between Openness and Reliability. Proceedings of the 39th Annual Hawaii International Conference on System Sciences (HICSS 06). doi: 10.1109 / hicss.2006.477

Von Krogh, G., Spaeth, S., \& Lakhani, KR (2003). Community, joining, and specialization in open source software innovation: a case study. Research Policy, 32(7), 1217-1241. doi: 10.1016 / s0048-7333 (03) 00050-7

To cite this document:

Fakhlina, R.J., \& Saputra, D.F. (2019). Development and Contribution of Open Source Software

Communities for the Library Progress in Indonesia. Record and Library Journal, 5(2), 150 - 159. 
West, J. (2003). How open is open enough? Research Policy, 32(7), 1259-1285. doi: 10.1016 / s0048-7333 (03) 00052-0

West, J., \& Gallagher, S. (2006). Challenges of open innovation: the paradox of firm investment in open-source software. $R$ and $D$ Management, 36(3), 319-331. doi: 10.1111 / j.14679310.2006.00436.x

To cite this document:

Fakhlina, R.J., \& Saputra, D.F. (2019). Development and Contribution of Open Source Software

Communities for the Library Progress in Indonesia. Record and Library Journal, 5(2), 150 - 159. 